\title{
Designing for ICT-Enabled Openness in Bureaucratic Organizations: Problematizing, Shifting, and Augmenting Boundary Work
}

\author{
Isam Faik ${ }^{1}$, Mark Thompson ${ }^{2}$, Geoff Walsham ${ }^{3}$ \\ ${ }^{1}$ National University of Singapore, Singapore, disif@nus.edu.sg \\ ${ }^{2}$ University of Exeter, UK, m.thompson6@exeter.ac.uk \\ ${ }^{3}$ University of Cambridge, UK, g.walsham@jbs.cam.ac.uk
}

Abstract

\begin{abstract}
There is a growing focus on achieving "openness" in the design and transformation of organizations, in which the enabling role of ICTs is considered increasingly central. However, bureaucratic organizations with rigid structures continue to face significant challenges in moving towards more open forms of organizing. In this paper, we contribute to our understanding of these challenges by building on existing conceptualizations of openness as a form of boundary work that transforms by challenging both internal and external organizational boundaries. In particular, we draw on a performative view derived from actor-network theory to analyze a case study of ICT-based administrative reforms in a judicial system. Building on our case analysis, we develop a typology of the various roles that ICTs can play in both enabling and constraining ongoing boundary work within the context of their implementation. We thus present a view of ICT-enabled open organizing as a process where ICTs contribute to problematizing, shifting, and augmenting ongoing boundary work. This view highlights the inherently equivocal nature of the role of ICTs in transformations towards higher levels of openness.
\end{abstract}

Keywords: Open Organizing, Organizational Boundaries, Boundary Work, Organizational Change, Actor-Network Theory, Justice System.

Dubravka Cecez-Kecmanovic was the accepting senior editor. This research article was submitted on September 13, 2015 , and went through four revisions.

\section{Introduction}

Organizational openness is increasingly recognized as an emerging phenomenon that is enabled by the transformative capacity of information and communication technologies (ICTs) (Ahmed, 2007; Baldwin \& von Hippel, 2011; Fishenden \& Thompson, 2012). Openness has become a key strategic imperative for many organizations, with various studies arguing that increased openness enhances accountability (Gigler, Tanner, \& Kiess, 2011), servitization (Yoo, Henfridsson, Lyytinen, 2010), social inclusion (Warschauer, 2004), productivity (Streeter, Kraut, Lucas Jr., \& Caby, 1996), expansion of supply chains (Sarker, Sarker, Sahaym, \& BjørnAndersen, 2012), and innovation (Laursen \& Salter, 2006). However, attaining these benefits remains elusive for large bureaucratic organizations with rigid structures (Gersick, 1991; Heracleous \& Barrett, 2001). While open forms of organizing manifest in online communities (von Hippel \& von Krogh, 2003) and multisided platforms (Boudreau, 2007), large and bureaucratic organizations continue to face significant challenges in making the change towards increased openness (Silva \& Hirschheim, 2007).

ICTs have been central to the discourses and practices that have shaped the drive towards openness in large organizations (Henfridsson \& Bygstad, 2013). A 
number of studies, including two recent special issues in the information systems field (Schlagwein, Conboy, Feller, Leimeister, \& Morgan, 2017; Whelan, Conboy, Crowston, Morgan, \& Rossi, 2014), have highlighted the centrality of ICTs to the increasing openness of the resources, processes, and outcomes of organizing. ICTs provide important elements of the enabling architecture required for a shift towards more open organizational structures (Monteiro, Pollock, \& Williams, 2014), as well as visible models for more open organizational dynamics through, for example, the open source software movement (Tkacz, 2012). On the other hand, ICTs have also contributed to making organizations less open by enabling higher levels of centralization (Whittington, Cailluet, \& YakisDouglas, 2011) or by becoming obligatory passage points for access to services (Backhouse, Hsu, \& Silva, 2006). In other words, ICTs play a dual role with regards to openness; they can make processes of organizing more open by increasing the permeability of organizational boundaries, and they can make them more closed by reinforcing existing boundaries.

A number of studies build on the concept of "boundaries" to offer a variety of approaches for linking the adoption and use of ICTs to varying levels of organizational openness. Some studies emphasize the role of ICTs in reducing the cost of coordination across organizational boundaries (Dewan \& Ren, 2011; Hitt, 1999). Other studies highlight the role of ICTs as boundary objects that offer interpretive flexibility enabling the spanning of knowledge boundaries (Levina \& Vaast, 2005). Yet others point to the role of ICTs in undermining established boundaries of professional identity, thereby opening professional fields to external participation (Lamb \& Davidson, 2005). However, the conceptualizations of openness proposed by such approaches tend to underemphasize the opposing practices that are continuously enacted to maintain and reinforce existing boundaries. Taking these practices into consideration is particularly important for understanding shifts towards open organizing in contexts with rigid structures, which are less readily amenable to changes in boundary configurations.

In response, we investigate the mechanisms through which ICTs both enable and constrain more open forms of organizing in the context of structurally rigid organizations. To do so, we adopt a practice-oriented view of openness as a form of boundary work. More specifically, we draw from actor-network theory's (ANT) conception of boundaries to develop a theoretical approach that highlights the dynamics between ICTs and ongoing boundary work in organizations. While there are several approaches to analyzing the role of ICTs in altering organizational boundaries (Hitt, 1999; Levina \& Vaast, 2005), ANT's relational ontology and performative epistemology (Cecez-Kecmanovic, Kautz, \& Abrahall, 2014) offer an approach that is particularly revealing of the tensions inherent to the dual role of ICTs in influencing organizational boundaries. In particular, a relational and performative perspective problematizes the stability of boundaries and shifts the analytical focus towards the work that goes into their construction and deconstruction.

We build our ANT-based conceptualization of ICTenabled open organizing on an in-depth study of judicial reforms in Morocco in which a large government modernization project was implemented in order to make the judicial system more open through the computerization of the courts. This large project, targeting more than 40 courts across the country and involving stakeholders from multiple sectors, highlights various types of boundary work that draw on ICTs to enhance the internal and external openness of the judicial system. The case is representative of the challenges that face openness projects and policies in contexts with rigid structures and entrenched boundaries.

We begin with a brief review of the literature on boundary work as a means of enabling and constraining the permeability of organizational boundaries and present the application of this literature to the conceptualization of ICT-enabled open organizing. We then present an actor-network approach to understanding boundaries, highlighting the advantages that this perspective offers to understanding the enabling and constraining dynamics of boundary work - and thus of organizations' ability to achieve greater openness. We then provide an account of a large ICT-enabled administrative reform initiative within the judicial system of Morocco, after which we apply our ANT lens to the case material, generating new insights about ICTs' role in problematizing, shifting, and augmenting boundary work - and thus in facilitating varying degrees of organizational openness. Finally, we develop broader theoretical and practical implications of these insights in a discussion on policies, processes, and practices of ICT-enabled open organizing.

\section{Boundaries, Openness, and Actor Networks}

\subsection{Boundaries and Boundary Work}

Boundaries represent discontinuities in practice (Levina \& Vaast, 2005), including the actions, perceptions, and objects that constitute practice. The analysis of boundaries has been an important approach to studying organizations (Santos \& Eisenhardt, 2005). Organizational boundaries, both internal and external, play a major role in shaping organizational structures and practices (Aldrich, 1971; Barrett, Oborn, Orlikowski, \& Yates, 2012; Carlile, 2002; Williamson, 1981). The literature on organizational boundaries presents various typologies, each identifying a 
different set of boundary types. For example, Santos and Eisenhardt (2005) distinguish between four types of organizational boundaries - namely, efficiency, power, competence, and identity boundaries. Efficiency boundaries demarcate between governance mechanisms such as hierarchy and market mechanisms, power boundaries demarcate between spheres of influence, competence boundaries demarcate between levels of access to resources, and identity boundaries demarcate between diverging perceptions of what an organization is about.

Ernst and Chrobot-Mason (2011) propose a different typology, which distinguishes between vertical, horizontal, stakeholder, demographic, and geographic boundaries. Vertical boundaries demarcate between organizational members based on relative levels of power and control in the organization. Horizontal boundaries differentiate between functions and knowledge groups. Stakeholder boundaries distinguish between the interests of the organization and those of its stakeholders. Demographic boundaries separate organizational members based on their personal attributes, such as race, gender, or education. Geographic boundaries separate organizational members based on their physical location. These typologies highlight the diversity of dimensions across which boundaries have been conceptualized. However, their underlying approach to conceptualizing boundaries is grounded in a representational view in which boundaries reflect demarcations that precede and set the conditions for organizational action.

Other approaches offer a more performative view, which focuses instead on boundary work - namely, the work involved in influencing boundaries. Performative approaches conceptualize boundaries as both the basis and outcome of organizational action. The concept of boundary work is central to these approaches and is defined as the "attempts of actors to create, shape, and disrupt boundaries" (Zietsma \& Lawrence, 2010, p. 190). It reflects the activities that "establish and maintain boundaries and manage interactions across those boundaries" (Faraj \& Yan, 2009, p. 604). Boundary work activities include constructing, maintaining, buffering, reinforcing (Faraj \& Yan, 2009), repairing (Bloomfield \& Vurdubakis, 1999), reconfiguring (Barrett et al., 2012), spanning (Levina \& Vaast, 2005), and disrupting boundaries. Some of these boundary work activities, such as spanning and disrupting boundaries, increase the permeability of existing boundaries, thereby enhancing the flow of information and resources across them. Such activities contribute to making organizing processes more open, either internally across the various units of organizations or externally towards their environment. Other boundary work activities, such as maintaining and reinforcing boundaries, entrench existing boundaries, making them obstacles to the flow of information and resources. The tensions between the two types of boundary work activities are particularly visible in fields that exhibit competing demands for more open but simultaneously more controlled boundaries, such as the public sector, where demands for higher democratic participation and accountability face the need for stronger regulations and bureaucratic processes (Callahan, 2007).

\subsection{ICT-Enabled Open Organizing as Boundary Work}

Studies of organizational openness have commonly associated the "opening" of organizations with changes in organizational boundaries-building, in particular, on how boundary work may constrain or enable permeability. In a systematic review of the openness literature, Dahlander and Gann (2010) highlight the way that most conceptual approaches to openness "emphasize the permeability of firms' boundaries where ideas, resources and individuals flow in and out of organizations" (p. 699). However, despite a growing interest in theorizing openness in the management literature, actually enacting open forms of organizing remains problematic. That is because organizing is commonly viewed as a process of establishing boundaries "between that which belongs from that which is outside" (Bloomfield \& Vurdubakis, 1999, p. 626). Therefore, open organizing reflects an inherent tension between the construction of boundaries as a quintessential organizing activity and their simultaneous deconstruction as the means to becoming more open.

These tensions are particularly visible when boundaries are entrenched in ways that render them taken-for-granted and thus intertwined invisibly with institutionalized structures. Entrenched boundaries reflect conditions that studies of organizational change have called structural inertia (Hannan \& Freeman, 1984), organizational inertia (Kelly \& Amburgey, 1991), or deep structure (Gersick, 1991). Such conditions represent "a persistent organizational resistance to changing architectural features" (Hannan, Laszlo, \& Carroll, 2002, p. 1), and hence a tendency to maintain and reinforce existing boundary configurations. The resulting entrenched boundaries combine multiple dimensions including beliefs and values, power distribution, organizational arrangements, control mechanisms, and technologies (Silva \& Hirschheim, 2007).

In response, organizations have begun to recognize the potential of ICT-enabled boundary work in disrupting deep structures and entrenched boundaries that might be limiting their agility and capacity to innovate. Some studies in this field have focused on the role of ICTs in reducing the cost of coordination and transaction across boundaries. For example, Malone, Yates, and Benjamin (1987) argue that ICTs reduce coordination 
costs leading organizations to move some of their internal activities beyond their external boundaries. Similarly, Gurbaxani and Whang (1991) highlight the role of ICTs in shifting both the external boundaries of organizations, by influencing their overall size, and their internal boundaries, by altering the distribution of decision-making authority. Rai, Pavlou, Im, and Du (2012) studied the role of ICTs in interfirm boundaries within the logistics industry and found that sophisticated ICT capabilities transform interfirm boundaries by making the complexity of the interdependencies between their processes more manageable.

Other studies have adopted more performative perspectives in which the role of ICTs in altering organizational boundaries is seen as emerging in practice. A major stream in these studies views ICTs as boundary objects (Star, 2010) that support the spanning of organizational boundaries (Levina \& Vaast, 2005), as well as their reconfiguration (Barrett et al., 2012) and disruption (Silva \& Hirschheim, 2007). Boundary objects are artifacts that increase the permeability of boundaries by being "plastic enough to adapt to local needs and constraints of the several parties employing them, yet robust enough to maintain a common identity across sites" (Star, 1989, p. 393). Levina and Vaast (2005) suggest that ICTs emerge as boundary objects when they help create a new joint field of practice that spans the boundary and provides a shared basis of legitimacy and understanding. Jonsson et al. (2009) studied knowledge boundaries in the use of remote machine diagnostic systems and concluded that ICTs contribute to boundary spanning by changing the nature of work across the boundary. Similarly, Barrett et al. (2012) studied the effect of digital innovation on occupational boundaries through a case of medication-dispensing robots in UK hospitals. In their case, the introduction of new ICTs led to a reorganization of the work of various occupational groups within the hospitals, leading to a reconfiguration of group boundaries through changes in status, authority, and control.

While these studies contribute to our understanding of how ICTs become part of the boundary work that increases the permeability and therefore the openness of boundaries, they do not emphasize in their analyses the tensions with the boundary work that goes into constructing and maintaining existing boundaries. Accounting for such tensions is particularly important in contexts with deep structures, which can make it particularly challenging to attain ICT-enabled transformation to established boundary configurations (Silva \& Hirschheim, 2007). It is in furthering our understanding of these tensions in the performance of ICT-enabled boundary work that we believe an actornetwork approach can make a useful contribution.

\subsection{An Actor-Network Approach to Conceptualizing Boundaries}

Actor-network theory started as a series of studies on the practice of science (Callon, 1986; Latour, 1987, 1988; Latour \& Woolgar, 1979), and evolved into a broader social theory (Latour, 2005; Law, 1999). Key to understanding the actor-network approach is the hyphen between the terms actor and network. Combining the two terms is meant to capture the idea that all actors, be it countries, organizations, individuals, or objects, are constituted of networks of heterogeneous elements. It also indicates that networks can become actors when they are stabilized through the continuous network-building actions of their constituting elements - an organization or a technological object is perceived as one actor if their connections become stable and enduring.

In conceptualizing boundaries, ANT advances a performative view that sees boundaries as always precarious and continuously enacted through the (net)work of human and nonhuman actors. In other words, boundaries demarcate between groups of heterogeneous entities and "if you stop making and remaking groups, you stop having groups" (Latour 2005 , p. 35). Yet, boundaries become entrenched when networks are black-boxed, meaning that they create structurally durable configurations (Law, 2009) and their internal relations become invisible (Latour, 1999). In turn, boundaries are challenged when actors are revealed as networks and their stability and consistency are no longer taken for granted.

Key to the processes of constructing boundaries is the role of spokespersons. Latour (2005) argues that "to delineate a group, no matter if it has to be created from scratch or simply refreshed, you have to have spokespersons which 'speak for' the group existence" (p. 31). Spokespersons can be individuals who accumulate enough legitimacy to represent a group, or they can be documents, graphs, or websites, for example, that both present a group to others and, in the process, define the group and demarcate its insidei.e., what is spoken for-from its outside. Therefore, spokespersons play a dual role in that they both span boundaries and ensure their continuity.

In "We Have Never Been Modern" (Latour 1993), which has been considered Latour's magnum opus (Harman, 2009), he distinguishes between two sets of boundary work processes: purification and translation. Latour (1993) discusses these processes in relation to the two concepts of nature and society, but we adopt them here in their broader sense. Purification processes reflect the work that goes into demarcating between entities, which involves constructing, maintaining, and reinforcing boundaries. Translation processes reflect the work that goes into the hybridization of entities, which involves the blurring, spanning, and disrupting 
of boundaries. For example, purification processes reflect the work that goes into separating the executive, legislative, and judicial powers, while translation reflects the processes through which these become entangled in practice. Purification processes reflect the work that maintains a distance between the inner workings of a technology and its users (e.g., user interface), while translation processes reflect the work through which users engage with the inner workings of the technology (e.g., bricolage, maintenance).

A key distinction between purification and translation is that the former turns boundary entities, on both sides of a boundary, into intermediaries that "transport meaning or force without transformation", while translation transforms boundary entities into mediators that "transform, translate, distort, and modify the meaning of the elements they are supposed to carry" (Latour, 2005, p. 39). Intermediaries can be complicated, but their output remains a direct function of their input, while mediators are complex and their actions are always underspecified. A complicated IT system can become an intermediary when it acts as a black box, while a simple IT artifact can be amediator if its identity remains problematic and subject to continuous negotiations - in other words, if it remains open to translation. Table 1 summarizes the distinction between translation and purification processes.

While the two processes of translation and purification are distinct, Latour (1993) argues that they depend on each other: "Without the first set, the practices of purification would be fruitless or pointless. Without the second, the work of translation would be slowed down, limited, or even ruled out" (Latour 1993, p. 11). Translation presumes the presence of boundaries across which it can be enacted, which means that it presumes purification processes that established those boundaries. Similarly, purification presumes some level of entanglement between entities, which means that it presumes translation processes that produced that entanglement. Callon (1999) uses the example of knowledge boundaries created by intellectual property rights and physical boundaries created by manufacturing processes to illustrate how purification processes often produce translation, entanglement, and overflow. He argues that:

It is by framing its property rights by
means of a public patent that a
pharmaceutical firm produces externalities
and creates overflowing. It is by purifying
the products that it markets that a chemical
firm creates the by-products which escape
its control. (Callon, $1999, \mathrm{p} .188$ )

In general, attempts at establishing or reinforcing boundaries between a firm and its environment can generate intended or unintended translations across those boundaries, while attempts at spanning or blurring the external boundaries of a firm can result in purifications across its internal boundaries. These dynamics between translation and purification reflect the tensions, which are inherent to boundary work, between the construction and deconstruction of boundaries.

This perspective offers several benefits for conceptualizing boundary work in new and theoretically generative ways. First, by presenting boundary work as a network building activity, it emphasizes a relational understanding of boundaries in which the existence of groups with clear boundaries depends on the work that continuously defines them in relation to others. This relational view represents one of the main advantages of boundary-focused theorizing: "If the notion of boundaries has become one of our most fertile thinking it is in part because it captures a fundamental social process, that of relationality" (Lamont \& Molnár, 2002, p. 169).

Second, the ANT perspective shifts the focus of analysis from taken for granted organizational boundaries to the heterogeneous actor networks that generate the different boundaries and maintains or reinforces them. In turn and third, it presents the construction and deconstruction of boundaries as interrelated processes. This emphasizes a performative view of boundary work that highlights the tensions and negotiations that go into the transformation of boundaries (Zietsma \& Lawrence, 2010).

Table 1. Distinction between Translation and Purification Processes

\begin{tabular}{|l|c|c|}
\hline & Translation processes & Purification processes \\
\hline Definition & Hybridization of entities & Demarcation of entities \\
\hline Types of boundary work & $\begin{array}{c}\text { Blurring, spanning, and } \\
\text { disrupting boundaries }\end{array}$ & $\begin{array}{c}\text { Constructing, maintaining, and } \\
\text { reinforcing boundaries }\end{array}$ \\
\hline Type of actor involvement & Mediators & Intermediaries \\
\hline
\end{tabular}

Fourth, instead of limiting the conceptualization of boundaries to those established between people or organizations, an ANT-based perspective opens the conceptualization of boundaries to those between heterogeneous entities, such as between people and artifacts or between people and organizations. 


\section{Research Methodology}

To investigate the processes of ICT-enabled open organizing, we adopted an interpretive case study research methodology (Walsham, 1995, 2006). Interpretive case studies provide a way of exploring a phenomenon in the richness of its context, which is important for studying a complex phenomenon such as ICT-enabled open organizing.

Our case is based on a large administrative reform initiative within the justice system of Morocco. The focus of our case was a project for the computerization of judicial processes in most courts around the country, with the stated objective of making judicial services more accessible to citizens. Data collection was conducted between October 2008 and December 2015. Preliminary visits to the field were conducted by the first author at the end of 2008, shortly after the launch of the computerization project in August of the same year. An extended study followed between April and July 2009 and three follow-up visits were conducted in May 2010, January 2011, and December 2015. The fieldwork included visits to 12 courts in six different cities around the country as well as several visits to the Ministry of Justice. Various levels of courts were visited, including first instance courts, appeal courts, and the Supreme Court. Each court visit lasted from one to three days, and some courts, such as those chosen as pilot sites, were visited multiple times. The various visits highlighted some important differences between the courts, which included differences in procedures, work culture, and attitudes towards interactions with the citizens, and revealed various boundaries that were intentionally or unintentionally maintained in the system.

Access to the research sites was facilitated by officials at the Ministry of Justice. While this type of access eased the movement across different courts, it made some officials in the courts hesitant to share their views because they perceived the computerization project as having been imposed by the ministry and resented being held accountable for its success. To overcome this challenge, we avoided the use of tape recording in interviews and resorted instead to diligent note-taking during and after each interview. This was deemed necessary to increase the level of comfort and trust among the participants. We also made sure to take note of our own thoughts and reflections during the interviews and used a coding scheme to differentiate them from the statements made directly by theparticipants.
Research methods included 57 semistructured interviews with 47 interviewees. Details of the interviews are shown in Table 2. The broad objective of the interviews was gaining a deep understanding of the digital transformation that the judicial system was undergoing. The focus on "openness" emerged later through data analysis. In addition, our interview protocol was refined after each interview to incorporate the acquired understanding in our conduct of the subsequent interview. Yet, most interviews aimed to elicit participants' interpretation of the changes that the ICT-based reforms were bringing to the judicial system. The interviewees were asked to elaborate on the shifts to their practices and their interactions with others resulting from the new technology and the new level of access provided by the system.

Other data collection methods included observations in clerk offices, courtrooms, court halls, IT departments, and training sessions for the new application. We also attended public debates on the reform of the justice system. These observations were helpful in providing a visual sense of some of the issues raised by the participants and in triangulating the reported findings. For example, observations in the courtroom revealed differences in the dress code between the clerks who use ICTs and those who do not, which was helpful in understanding the identity boundary between the two groups. The data corpus for the case also included internal and external documents. The former included internal reports, memos, and presentations, while external documents included publicly available reports from international organizations and press articles. Such articles were abundant given the significant debates over judicial reforms in the public discourse at the time period of the study. These articles and reports were particularly helpful in understanding the historical background of the case as well as itsbroader political and social context.

Data analysis in interpretive case studies is often based on the use of a chosen theory to support the iterative process between data collection and analysis (Walsham, 2006). In this study, ANT was adopted in the study design stage for the purpose of theoretical scaffolding to help guide data collection, but was then retained for theory development as well. The use of ANT maintained our analytical focus on the ongoing practices of the human and nonhuman actors in the field. It provided safeguards against rapid jumps to theoretical constructs or causal understandings that are not followed through the networks of practices enacted through the various organizational processes. 
Table 2: List of Interviewees and Number of Interviews

\begin{tabular}{|l|c|c|}
\hline Interviewee category & Number of interviewees & Number of interviews \\
\hline Court clerks from various departments & 11 & 11 \\
\hline Head clerks & 3 & 3 \\
\hline Court network administrators & 7 & 5 \\
\hline Judges (including presidents of courts) & 5 & 3 \\
\hline Prosecutors & 3 & 6 \\
\hline Lawyers & 6 & 9 \\
\hline Senior officials at the Ministry of Justice & 4 & 2 \\
\hline Engineers at the Ministry of Justice & 1 & 3 \\
\hline Employees at the Ministry of Justice & 2 & 3 \\
\hline Trainers for the MEDA project & 3 & 1 \\
\hline Consultant for the MEDA project & 1 & 3 \\
\hline Engineer at system provider & 1 & $\mathbf{5 7}$ \\
\hline Total & $\mathbf{4 7}$ & \multicolumn{2}{|c|}{} \\
\hline
\end{tabular}

\section{Case Findings}

Over the last two decades, the government of Morocco embarked on various initiatives with the aim of addressing some of the challenges facing the judicial system. These challenges included difficulties faced by economically and geographically marginalized communities in accessing the system, perceived lack of independence of the judiciary from the executive power, corruption across different levels of the system, and lack of efficiency in judicial administration (Greene, 2012). An important part of the reform agenda was the "modernization" of the courts, which, in this case, was largely associated with an ICT-based project called MEDA ${ }^{1}$ (Faik \& Walsham, 2013).

The MEDA project involved the development of a new case processing application (called SAJ) and its deployment in 40 selected courts around the country. The SAJ application was developed locally with the objective of enabling the comprehensive computerization of the various procedures in the courts. Figure 1 presents the major procedures included in the application and the reference tables on which they were built.

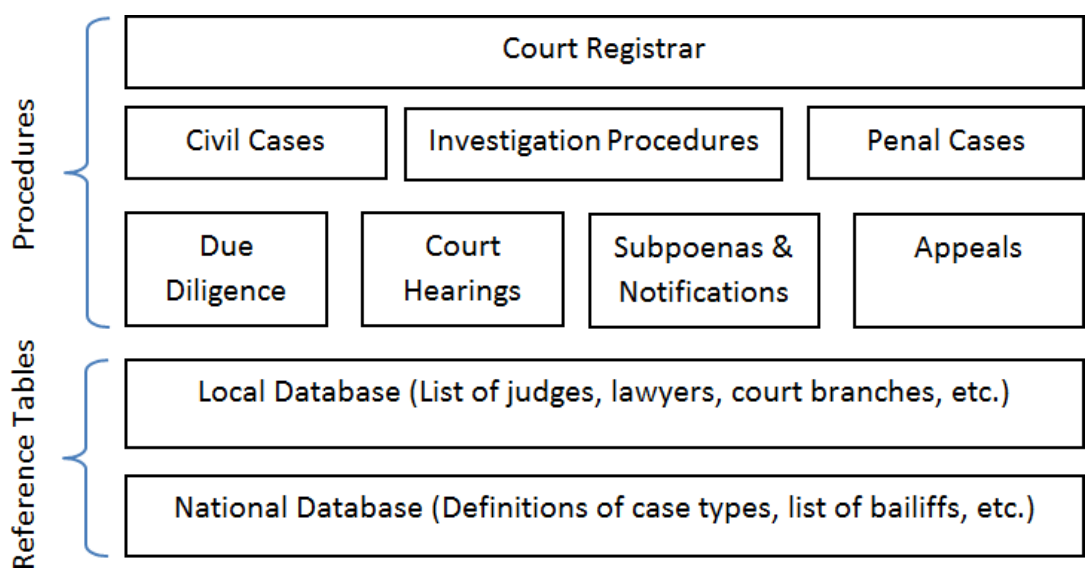

Figure 1. Major Components of the SAJ Application (Adapted and Translated from Internal Document)

${ }^{1}$ Named after the financial instrument of the European Union's Euro-Mediterranean Partnership, which accounted for $80 \%$ of its budget. 
Along with the computerization of the back-office operations in the courts, the project was also intended to achieve shifts in front-office interactions with the citizens. For example, in addition to digitizing all the ongoing cases in the courts, the project included the installation of computer stands in court halls. The objective was to allow citizens and lawyers to follow the status of their cases without having to go through the intermediation of court clerks. Another aspect of the changes to the front-office operations was the development of e-justice portals for each court. These websites were supposed to allow lawyers and their clients to follow judicial cases online and consequently reduce the need to be physically present in court buildings.

The context in which the MEDA project was deployed presented a variety of boundaries that shaped the evolution of the project. The following subsections describe the organizational and operational structures that defined the internal and external boundaries of the system, as well as the tensions that made those boundaries more visible.

\subsection{Early Computerization in the Courts: Changing Boundaries between IT and Judicial Practices}

Computerization in Moroccan courts started in the early 2000s with two small projects. The first was a World Bank-financed project to develop a case processing application for the commercial courts. The application was developed by engineers from the Ministry of Justice and was deployed in all six existing commercial courts. It was then adapted and deployed in the civil section of a few selected courts around the country.

In parallel with this project, a general prosecutor from the court of a small city east of the country developed a personal interest in information technology and took the initiative of developing an application for the penal section of the courts - the penal and civil procedures are substantially different and required significantly different systems. The penal application was based on Microsoft Access and was first used in the local court of the developer before it was brought to the attention of senior administrators at the ministry and subsequently distributed to other courts around the country.

Despite the relatively limited scope of these two projects, the new IT system became increasingly entangled with existing judicial processes. For example, while the use of paper registers for tracking cases continued in all the courts, several judicial operations, such as the retrieval of case statuses or the printing of subpoenas, became highly dependent on the two systems. However, because these were early stages of computerization in the courts, attempts to embed the newly implemented system so that it could function on a standalone basis were not very effective. For instance, an engineer from the ministry championed the first project and played a critical role in its development and deployment, which meant that the functioning and quality of the application continued to be attached to his presence, long after the implementation of the system:

There were problems because the engineer was not here full time. We paid the price of being a pilot project without having enough resources. The engineer was the only one to have the source code. This application involves much experimentation. If we had a developer here we would have a much better tool. (IT administrator in a commercial court)

In this case, ineffective boundaries between the system and its designers constrained the interactions between the users and the system and constrained its ability to function independently. Yet, by starting to transform courts into hybrid environments that were infused with IT, albeit at a limited scale, these early computerization projects brought to light the work that goes into the establishment of different boundaries, particularly those that were perceived as entrenched in the judicial system. For example, with the introduction of the two systems into the courts, the need for IT governance to determine the responsibilities of development, maintenance, and upgrade revealed some of the fault lines between the Ministry of Justice and the courts. The need to attend to continuous changes in IT processes highlighted the requirement for open twoway communication between the courts and the ministry - the lack of which resulted in several complaints by court administrators. Despite its limited effect on the power differential between the ministry and the courts, the introduction of ICTs made this differential more problematic.

\subsection{Defining the Scope of the MEDA Project: Changing Boundaries within and Between Judicial Organizations}

In 2004, planning for the MEDA project started with a large consultation phase that involved both international and local consultants, who visited the courts and conducted focus groups to define the scope of the project. The consultants left before the implementation started in 2007, but the reports they produced shaped several boundaries of the MEDA project. These boundaries defined which parts of the justice system were going to be digitized through the project and which ones were going to continue with paper-based processes or be digitized through other projects. The justice system involved a wide range of stakeholders, including the courts, the Ministry of Justice, the High Magistrate Council (the professional 
body for judges), the lawyers, the bailiffs, the professionals certified to provide judicial expertise in various fields such as health and real estate, the police, the penitentiary institutions, and the citizens using the courts. Most judicial processes involved the combined actions of several of these entities, which complicated the process of delimiting the boundaries of the MEDA project.

The Ministry of Justice, as the main manager of the judicial system, was the owner of the project. It controlled its finances, procurement, staffing, and training. The Ministry had direct control over the administrative matters of all the regular courts, but they had limited control over other entities in the system. For example, historical tensions between the Ministry and the Supreme Court over the level of independence of the latter from the Ministry meant that it was never considered as a site for implementation of the new SAJ application. In addition, while several police units fall under the organizational control of the crown prosecutors, which are part of the court system, the police were also kept outside of the computerization project, despite their processes representing direct input to the judicial system.

In addition, the court system included different types of courts at varying levels of judicial authority and specialization. However, as shown in Figure 2, The MEDA project was limited to the courts of appeal, and the first instance courts. The more specialized courts, such as the commercial and administrative courts were excluded from the project, at least in its initial stages. Also excluded were the lower level representations of the justice system, such as residence judges (judges operating in communities, outside the main court building) and communal jurisdictions (appointed juries in rural areas), which are established to bring judicial services closer to the citizen.

Even between the courts that were selected to be within the scope of the MEDA project there were many boundaries that made it challenging for citizens to access any court beyond the one in which their cases originated. That is because the transfer of files between courts required a level of standardization in file categorization and treatment processes that was limited by the structural boundaries between the different courts. An application developer and trainer for the MEDA project highlighted this challenge when comparing it with the first two applications:

\section{Those applications cannot achieve what the $M E D A$ application can: the standardization of the employees' behavior Only recently I started appreciating what the project manager told me at the beginning of the project: We should not worry too much about the proper functioning of the application at this stage, but we should strive for the data in it to have the same meaning [across courts].}

In addition to the boundaries between the courts, established boundaries within the courts also contributed to shaping the scope of the MEDA project. Moroccan courts are divided into two sections: the main court and the prosecution. All penal cases start on the prosecution side of the court and are then transferred to the main court to be scheduled for court hearings.

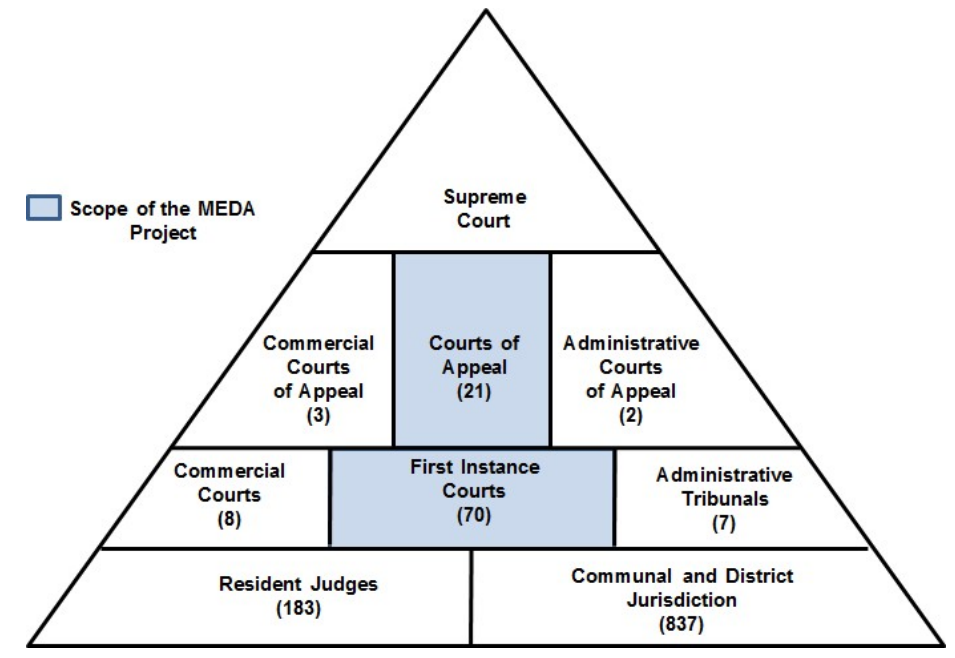

Figure 2. Judicial Organization Across Jurisdictions (Number of Courts in 2016) 
In contrast, civil cases start directly at the main court and follow a relatively simpler process in their progression through the system. In fact, each of the two applications that were in operation in the courts prior to the MEDA project were developed for only one side of the court - one for the civil side and one for the penal side. As a result, many courts had only their penal processes computerized while other courts had only their civil processes computerized. Being a much larger project, the MEDA project needed to transcend the boundaries between the two parts of the court system. Determining the right approach to achieving this objective was a significant challenge for project managers, as reflected by a senior manager of the MEDA project, who stated: "If we were to start the project from scratch, we would separate the development and implementation of the civil and penal parts of the SAJ application". Introducing the SAJ application against the background of the historical accumulation of organizational entanglements between different parts of the court system created the need for internal boundaries capable of simplifying the conception and implementation of the system.

\subsection{Implementing the MEDA Project: Changing Boundaries Between Judicial Processes}

According to a senior officer of the MEDA project, one of the main objectives of the MEDA project was "the establishment of a front office/back office mentality" among the users and the clerks of the courts. Before computerization, citizens were able to move around the court offices trying to find the right person to ask for information related to their cases. Later, the courts in which the new application had been deployed started limiting access to the clerk offices and requiring people to use the computer stands in the court halls or the new reception desks, which had access to the application and could serve those unable to use the computer stands. In addition, court users could also access information in the courts through the newly developed web portals for each court.

The implementation of the SAJ application had the effect of constructing a boundary between the backend processes of the courts, on the one hand, and the citizen-facing processes on the other. Court records were no longer "spoken for" by the clerks, but by the new IT artifacts (computer stands, web portals, reception desks, etc.). Citizens using the courts had more direct access to information but less access to the clerks. Physical access to the court buildings became more controlled through increased security at their entrances. These changes were making the courts more physically closed by making them more informationally open.
However, these changes depended on a view of court users as intermediaries whose actions were expected to reflect the designed shifts of the boundary configurations of the courts. Instead, the case reveals a more active engagement by users in shaping the new boundaries. Citizens using the courts tended to combine the intensity of their quest for information with a felt need for continued physical presence in the courts and a heightened emotional engagement with court procedures, given the potential significance of their outcomes on themselves or on their family members. As explained by a general prosecutor:

There are particularities to judicial practice. The citizen still wants to talk to the judicial administrator. The law allows me to force people to accept the information from the reception desk, but we need to be flexible. At the beginning, we need to convince. Judicial administration is an administration of the human psyche. (general prosecutor at a court)

Court users continued to demand physical access and face-to-face interactions with court officers and clerks. In addition, various practices that depended on this physical access were entrenched in the way many users approached the courts. For example, it was common for court users to pay small bribes to court clerks to get information about their cases. Even after the computerization of the courts, many people still felt the need to pay for the information they obtained in order for them to consider it reliable. Many were unable or unwilling to accept information from the reception desks or the computer stands in the court halls:

Many citizens do not think proper
information can be free. I would give some
people all the details of their case [from the
computer stand in the court hall] and they
would go and ask the same questions to
someone else to whom they would pay a
bribe. (court IT administrator)

In addition, implementing the SAJ application also reinforced the boundary between judicial information and the clerks responsible for capturing it from case files and court hearings. This was achieved, for example, by limiting the ability of the clerks to alter the data once it is entered into the system. Alterations had been easier with the old pen and paper system, which blurred the boundary between the intentions of the clerks and the records they produce and maintain. The blurring of this boundary was a major challenge for the court system before the SAJ application. A senior MEDA manager explained this challenge with regards to court registrars who receive the files and payments for civil cases and record them in their registers: "Every time there is a nationwide audit, two or three court registrars will get caught and sentenced to prison, 
and whole families get destroyed". However, reinforcing this boundary based on the new application encountered major challenges. The use of the new application required the hiring of hundreds of young clerks who would use the new IT system instead of the paper registers. This was seen as important for the transition period in order to support the more senior clerks in using the application. However, since the new recruits were not using the paper registers, their identity was fully associated with the new system. In fact, they were commonly referred to in the courts and the ministry as "technicians", despite officially being regular clerks similar to all others. This reinforced the resistance of the older clerks to use the new system. As stated by a MEDA project manager:

There is a lot of resistance from many clerks. What happens is that the "technicians" will go to help the users in particular departments and they end up doing all the work on the system while the regular clerks continue using their paper registers.

\subsection{Impact of the MEDA Project: Changing Boundaries Between Judicial Values}

In addition to improving the efficiency of judicial processes, a key objective of judicial reforms, such as those involving the MEDA project, is to improve the quality of the outcome of judicial services: the rulings issued by the judges. In the MEDA case, the effect of the application on the rulings issued at the end of long judicial processes was a matter of contention between the various project stakeholders. Several boundaries were perceived to limit the reach of the application's influence, particularly with regards to the decisionmaking process of the judges. As explained by a senior officer at the Ministry of Justice and former judge: "There is no area that escapes computerization.... But we cannot change the head of the judge. Justice has a human side to it".

The decision-making processes for the final rulings were perceived by most actors in the field to be beyond what can be subject to computerization. The extent of the SAJ applications' influence on the rulings was limited in their view to its effect on administrative processes as background work for the judges' decisionmaking. As explained by a senior officer at the Ministry of Justice and former prosecutor: "A good quality ruling is one that it is just and humane, fast while respecting procedures, and effective...meaning that it gets enforced. The SAJ application will affect the preparatory work for the judge to issue the ruling". This perception of limits on the effects of the application depended on an entrenched boundary between the judges as legal professionals and other actors as pure administrators. However, this boundary was being challenged by various stakeholders, particularly those who were structurally outside the court system, such as the lawyers. As one lawyer (head of a regional lawyer's association) exclaimed: "What would judges do with their honesty if they have in front of them a made-up police report, a falsified document, and a false expertise?".

Such proclamations were challenging the entrenched demarcation between the court rulings and the judicial processes on which they are based, seeing them as inextricably linked. The implementation of the SAJ application did not directly challenge this demarcation. Most judges were provided with new laptops as part of the MEDA project, but the objective was mainly to have them type their rulings instead of writing them by hand, with little emphasis on the use of the application. However, some study participants did suggest ways in which they saw the effects of the application on the administrative processes to extend to the rulings of the judges. For example, an engineer involved in the implementation of the SAJ application argued, in a group discussion, against the dominant view that the application had little effect on the rulings of the judges by stating: "The application cannot directly affect the level of corruption amongst the judges, but by reducing the time it takes to treat files, it leaves less time for them to be influenced by outsiders".

Furthermore, the effects of the new application on the boundaries between the multiple values upheld by actors in the judicial field manifested also in the relationship between the lawyers and their clients. For many court users, their lawyers appeared to have complete control of all the procedures related to their court cases, which limited the transparency of these procedures and that of the lawyers' role. However, the application supported the quest on behalf of some citizens quest for increased transparency and challenged the established role of the lawyers. As explained by a lawyer in a pilot court for the MEDA project:

The lawyer still does not accept that the client follows the case step by step. When the clients know that a court hearing is scheduled in two weeks, they have expectations for that date. It is different if they hear that there is an adjournment or any other ruling from the lawyer than if they get it from the application. On the other hand, we can tell them to go check the application if they do not trust us. Transparency is good for us; in case you get tempted, you know that your client can have the information. (lawyer in a first instance court)

By becoming actively engaged rather than passively accepting of the boundary with the courts, the court users were challenging the authority of the lawyers. 
The information differential that was giving the lawyers an advantage over their clients was being reduced by making the court system more open to the citizens. In this case, changing the boundaries of the system was not only transforming relations across those boundaries, but also the boundaries between actors that are considered outsiders to the court system, such as the lawyers and their clients.

\section{Case Analysis: ICTs, Boundary Work, and Open Organizing}

When viewed through our ANT-based lens, the MEDA case reveals ICT-enabled open organizing as a formof performative boundary work that involves both the construction and deconstruction of boundaries in a tension between ongoing processes of purification and translation. Revealing this tension has enabled increased visibility of the dynamics involving, on the one hand, the new boundary work enabled by ICTs and, on the other, the opposing boundary work that maintains and reinforces existing boundaries. Thus, our analysis is not limited to examining ICTs as a means to increased openness; instead, it highlights the inherently equivocal nature of the role of ICTs in the openness of organizing practices. Our lens draws attention to the role of ICTs in the continual enactment, and temporary resolution, of ongoing tensions between the construction and deconstruction of various types of boundaries between practices, organizations, processes, and values. In particular, our case analysis highlights three distinct roles that ICTs play in reshaping the performance of boundary work through which organizations enable, or constrain, openness: namely problematizing, shifting, and augmenting boundary work (Table 3 ).

Table 3: Roles of ICTs in Reshaping Boundary Work and Their Effects on Openness

\begin{tabular}{|c|c|c|c|c|}
\hline $\begin{array}{l}\text { Role of ICTs in reshaping } \\
\text { existing boundary work }\end{array}$ & $\begin{array}{c}\text { Openness } \\
\text { enabling effects }\end{array}$ & $\begin{array}{c}\text { Illustrations from the } \\
\text { case }\end{array}$ & $\begin{array}{c}\text { Openness } \\
\text { constraining } \\
\text { effects }\end{array}$ & $\begin{array}{c}\text { Illustrations from the } \\
\text { case }\end{array}$ \\
\hline $\begin{array}{l}\text { Problematizing boundary } \\
\text { work: } \\
\text { Revealing ongoing } \\
\text { translation/purification } \\
\text { processes }\end{array}$ & $\begin{array}{l}\text { By revealing } \\
\text { ongoing } \\
\text { purification } \\
\text { processes, ICTs } \\
\text { enable new } \\
\text { translation } \\
\text { processes }\end{array}$ & $\begin{array}{l}\text { By bringing attention to } \\
\text { some of the purification } \\
\text { processes that } \\
\text { maintained the power } \\
\text { boundary between the } \\
\text { courts and the ministry, } \\
\text { the MEDA project } \\
\text { enabled translation } \\
\text { across the boundary } \\
\text { between them }\end{array}$ & $\begin{array}{l}\text { By revealing } \\
\text { ongoing translation } \\
\text { processes, ICTs } \\
\text { enable new } \\
\text { purification } \\
\text { processes }\end{array}$ & $\begin{array}{l}\text { By revealing the } \\
\text { ongoing translations } \\
\text { between the two sides of } \\
\text { the court system (main } \\
\text { court vs. prosecution), } \\
\text { SAJ application enabled } \\
\text { increased purification } \\
\text { between them }\end{array}$ \\
\hline $\begin{array}{l}\text { Shifting boundary work: } \\
\text { Enabling translation by } \\
\text { building on ongoing } \\
\text { purification OR enabling } \\
\text { purification by building on } \\
\text { ongoing translation }\end{array}$ & $\begin{array}{l}\text { By enacting } \\
\text { purification } \\
\text { processes, ICTs } \\
\text { enable translation } \\
\text { processes }\end{array}$ & $\begin{array}{l}\text { By enacting purification } \\
\text { across the boundary } \\
\text { between court records } \\
\text { and the practices of the } \\
\text { clerks, the SAJ } \\
\text { application enabled } \\
\text { translation across the } \\
\text { boundary between court } \\
\text { records and citizens }\end{array}$ & $\begin{array}{l}\text { By enacting } \\
\text { translation } \\
\text { processes, ICTs } \\
\text { enable purification } \\
\text { processes }\end{array}$ & $\begin{array}{l}\text { By enacting translations } \\
\text { between the identity of } \\
\text { the young clerks (the } \\
\text { "technicians") and } \\
\text { computer machines, the } \\
\text { SAJ application enabled } \\
\text { purification between the } \\
\text { identity of old and } \\
\text { young clerks }\end{array}$ \\
\hline $\begin{array}{l}\text { Augmenting boundary } \\
\text { work: } \\
\text { Enabling } \\
\text { translation/purification by } \\
\text { enhancing ongoing } \\
\text { translation/purification } \\
\text { processes }\end{array}$ & $\begin{array}{l}\text { By enhancing } \\
\text { ongoing } \\
\text { translation } \\
\text { processes, ICTs } \\
\text { enable new } \\
\text { translation } \\
\text { processes }\end{array}$ & $\begin{array}{l}\text { By building on the } \\
\text { ongoing translations } \\
\text { across the boundary } \\
\text { between the citizens } \\
\text { and the courts, the SAJ } \\
\text { application enabled } \\
\text { translations across the } \\
\text { boundary between the } \\
\text { citizens and the lawyers }\end{array}$ & $\begin{array}{l}\text { By enhancing } \\
\text { ongoing } \\
\text { purification } \\
\text { processes, ICTs } \\
\text { enable new } \\
\text { purification } \\
\text { processes }\end{array}$ & $\begin{array}{l}\text { By enhancing the } \\
\text { demarcation between the } \\
\text { practices of the judges } \\
\text { and those of other actors } \\
\text { in the judicial field, the } \\
\text { MEDA project enabled } \\
\text { a demarcation between } \\
\text { the fairness of the } \\
\text { system and its efficiency }\end{array}$ \\
\hline
\end{tabular}




\subsection{Problematizing Boundary Work}

The first identified role of ICTs in the opening of organizing practices in the judicial system is the problematizing of ongoing boundary work. On the one hand, the introduction of ICTs into the system revealed the work that effectively maintained and reinforced entrenched boundaries. For instance, the development and implementation of the SAJ application and the two applications that preceded it drew attention to some of the communication and governance issues that had maintained informational and power boundaries between the courts and the Ministry of Justice. In turn, revealing these purification processes instigated translation processes capable of spanning the entrenched boundaries. For example, 30 clerks from different courts around the country were hired and stationed in the Ministry to help with the application development. They were then deployed to different courts to train the new users and to help with the configuration of the application to fit the organizational structure of each court. Through these multiple roles, these clerks acted as boundary spanners between the Ministry and the courts. In this case, the introduction of ICTs instigated dynamics between purification and translation that increased the level of openness across the boundary between the Ministry and the courts.

On the other hand, the case also showed how the introduction of ICTs constrained openness when it enabled purification processes by revealing ongoing translation activities. For example, the computerization of the courts brought to light some of the entanglements between the two sides of the court (main court and prosecution), such as the large number of times that a penal file travels back and forth between the two sides during the judicial process. Increased complaints about the lack of completeness of files when entered into the new system prompted many head clerks to reinforce the boundary between the two sides of the court. Some went as far as creating a stamp that said "Computerized" to be used for marking the physical files that have been fully and properly entered into the system by either side of the court. In this case, the introduction of ICTs instigated dynamics between purification and translation that constrained open organizing across the boundary between the two sides of the court.

\subsection{Shifting Boundary Work}

The second identified role of ICTs in the opening of organizing practices is a shifting of ongoing boundary work-again, in a way that either enabled or constrained openness. On the one hand, the new ICTs enabled translation processes by enacting new purification processes. For example, the SAJ application enabled translation across the external boundary between court records and the court users (citizens and lawyers) by enacting purification across the internal boundary between court records and the practices of the clerks. The control and traceability afforded by the new system made the court records less open to alterations based on the intentions and unauthorized actions of the clerks. The resulting increase in the stability of court records made them more amenable to direct sharing through the e-justice portals and computer stands in the court halls, which afforded court users better access and visibility of their records. In this case, reinforcing the courts' internal boundaries increased the permeability of theirexternal boundaries. Therefore, the introduction of new ICTs worked to shift the locus of boundary construction from one part of the system (external boundaries) to another (internal boundaries). This rendered the system more open to its external stakeholders.

On the other hand, ICTs can also shift boundary work in ways that constrain openness. This occurs when ICTs enable purification by enacting new translation processes. For example, the discourse that accompanied the implementation of the SAJ application heightened translations across the boundary between the new system and a specific category of court clerks - the large number of new and young employees who were commonly referred to as "technicians". The latter were distributed across the courts nationwide and across the departments of each court with the objective of enhancing system usage. However, the translations enacted between their identity and the SAJ application through the discourse that called them "technicians" generated an identity boundary between them and the older clerks. The older clerks viewed themselves, in opposition, as "legal" administrators and consequently left most activities involving the application-which they considered "technical"- to the new employees.

\subsection{Augmenting Boundary Work}

The third identified role of ICTs in in the opening of organizing practices is augmenting ongoing boundary work-once again in ways that either reinforce or constrain organizational openness. In augmenting boundary work, ICTs can enable increased openness by building on ongoing translation processes. For example, the SAJ application enabled translation across the boundary between the court users and their lawyers by enhancing ongoing translation between the citizens and the court system. The increased permeability of the boundary between citizens and their court records challenged an entrenched power boundary between the citizens and their lawyers, which was based on an information asymmetry that kept many citizens in the dark with regards to the progression of their cases, rendering them dependent on their lawyers and vulnerable to potential fraudulent 
behavior. Thus, the application not only enhanced the ongoing boundary work in challenging the demarcation between the citizens and their court records, but it also augmented the boundary-disrupting effects of that work to include the boundary between the citizens and their lawyers. This contributed to reducing the layers of mediation between the citizens and the court system, enhancing its openness to citizens.

On the other hand, the case also indicates that augmenting boundary work through ICTs can also constrain openness. This occurs when ICTs enable new purification processes by enhancing or building on ongoing work of purification. For example, The MEDA project enabled purification across the boundary between the perception of fairness in the system and the perception of its efficiency by enhancing purification across the practice boundary between the judges and other actors in the judicial system, such as administrators, lawyers, bailiffs, and the police. The various stakeholders of the judicial system formed their perceptions of how fair and just it is mostly based on the judges' rulings, which were seen as separate from the myriad activities that inform the elaborate decision-making process through which they are generated. Some voices were challenging this perception by opening the black box of the rulings and highlighting their dependence on the efficiency and reliability of the various processes that contribute to their shaping. However, the demarcation between the work of the judges and all other judicial processes was entrenched in the perception, discourses, and practices of most stakeholders in the judicial field. Implementing the SAJ application enhanced the boundary between judges and other actors in the field, since the main work of the judges was largely perceived to be unaffected by the application. As a result, the application reinforced an existing perception of the fairness of the system as distinct from the efficiency and reliability of its processes, despite

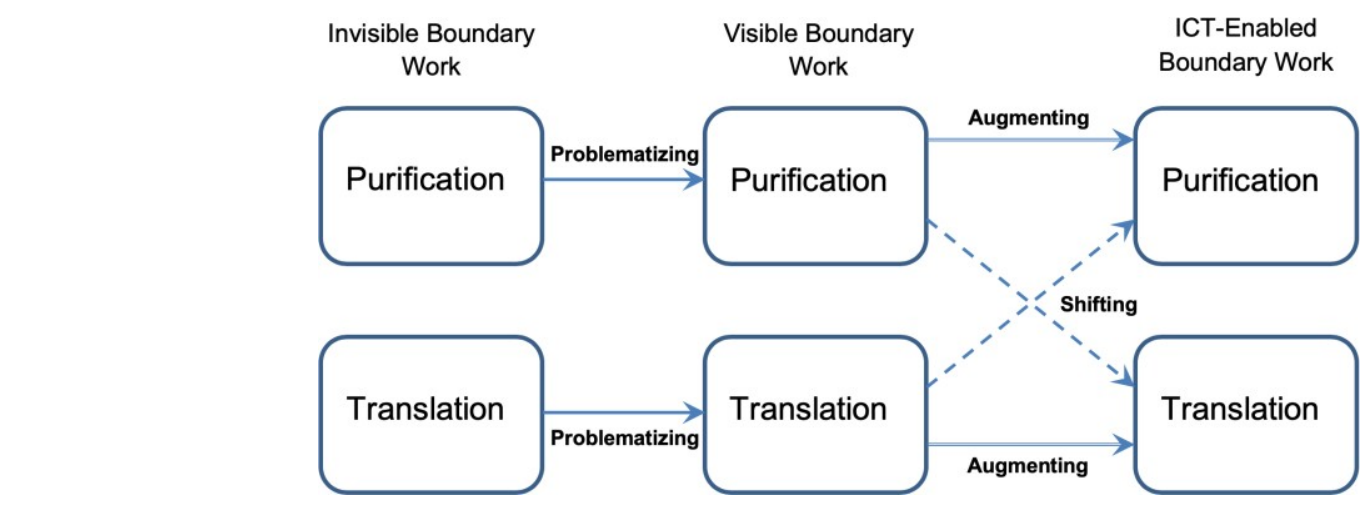

Figure 3. A Typology of the Roles of ICTs in Reshaping Existing Boundary Work ongoing attempts at challenging this perception. Thus, the application augmented the ongoing boundary work concerning the boundary between the judges and the other judicial actors in ways that reinforced the boundary work concerning the boundary between the fairness and efficiency of the system.

\section{Discussion}

Studies of open organizing in the information systems and organization studies literatures have largely focused on fields exhibiting relatively high levels of openness, such as open source software communities (Aksulu \& Wade, 2010; Shah, 2006), digital platforms (Boudreau, 2007), and open innovation networks (Eservel, 2014; Lakhani, Lifshitz-Assaf, \& Tushman, 2013). Less attention has been directed towards challenges faced byorganizations with rigid structures in moving towards more open forms of organizing. To develop a theoretical understanding of these challenges, our ANT-based perspective presents a conceptualization of ICT-enabled open organizing that highlights the entanglement of ICT processes with ongoing boundary work that maintains and reinforces existing boundary configurations. It draws attention to the continual enactment, and temporary resolution, of ongoing tensions between the construction and deconstruction of boundaries as ICTs become intertwined with ongoing boundary work. In so doing, it reveals the inherently equivocal nature of the role of ICTs in transformations towards more open forms oforganizing.

Through the application of our ANT-based perspective to the analysis of the MEDA case, we developed a typology of the roles that ICTs can play in affecting ongoing boundary work within the context of their implementation. We identified three ideal types of such ICT-enabled boundary work - namely, problematizing, shifting, and augmenting ongoing boundarywork. 
These types are not necessarily exhaustive of all possible roles that ICTs can play in altering boundary configurations, but they offer an understanding of these roles that emphasizes the entanglement of ICTs with the tensions inherent to boundary work-specifically between translation and purification processes. Figure 3 presents a summary of the proposed typology.

ICTs problematize boundary work when they render both purification and translation processes more visible and consequently more readily challenged or supported by organizational stakeholders. They shift boundary work when they build on ongoing purification activities, such as the construction of new boundaries or reinforcing of existing ones, in ways that make other boundaries more permeable, or when they build on ongoing translation activities - such as the spanning or blurring of boundaries - in ways that reinforce other boundaries in the system. Finally, ICTs augment boundary work when they build on the translation discourses and practices that are already challenging entrenched boundary configurations in ways that enable further translation across various boundaries in the system, or when they build on the work that reinforces entrenched boundary configurations in ways that add new layers or dimensions to existing boundaries.

This typology and its underlying ANT-based perspective offer several implications for our understanding of the challenges facing large and rigid systems in using ICTs to transform their mode of organizing towards higher levels of openness. We discuss here three key implications. First, it suggests a shift of emphasis in understanding the role of ICTs in openness away from a focus on the functions of the technology, such as communication and coordination functions (Malone et al. 1987; Rai et al., 2012), towards a broader consideration of how ICTs can be used as a catalyst to enable higher visibility of existing boundaries and the work that goes into maintaining and reinforcing them. Such visibility is important if the boundaries are to be challenged and opened up to support greater participation by various stakeholders. That is particularly the case when the boundaries being challenged by ICTs are part of the "deep structure" of a system; that is, when they reflect the "trail of choices made by [the] system" over extended periods of time and the basis on which it "rules many options out" (Gersick, 1991, p. 16), including options for alternative boundary configurations.

Achieving radical shifts in the structure of a system from a bureaucratic to a more open culture can pose a major challenge, especially where the need for control and accountability across processes, policies, and regulations, combine to make certain systems such as those in the public sector intrinsically more complex to "open up". Thus, problematizing existing organizational boundaries by rendering them visible to the collective and available for explicit discussion may improve the chance that the purification and translation associated with the introduction of new ICTs may actually achieve the desired forms of open organizing through new boundary configurations. Understanding how ICTs reveal boundary work thus emerges as an important capability for the design and implementation of ICTs for the transformation of large and bureaucratic organizations.

Increased visibility of boundary work provides organizational actors a degree of control over the way in which organizing structures and practices can be transformed through ICTs. It allows them to adapt the implementation of ICTs in ways that attend to desired boundary configurations. However, on the one hand, they can deploy ICTs in ways that make them "spokespersons" for organizational members, turning them into intermediaries that simply transfer the algorithmic commands of the technology into predefined actions. Such ICT use is likely to constrain the ability of the organization to shift or augment the ongoing boundary work towards more open organizing. On the other hand, ICTs can be deployed in a way that problematizes existing boundary work, turning organizational members into mediators that can challenge prescribed boundaries and facilitate higher levels of openness.

Second, the proposed ANT-based perspective extends the performative view offered by studies that emphasize the role of ICTs as boundary objects that enable boundary spanning (Barrett, Oborn, Orlikowski, \& Yates, 2012; Jonsson, Holmström, \& Lyytinen, 2009; Levina \& Vaast, 2005). It does so by highlighting the relationship between boundary spanning, which is a translation process, with ongoing purification processes. On the one hand, it indicates that ICTs, can act as boundary objects yet become elements of the system's deep structure. As shown in the MEDA case, ICTs can enable translation processes while at the same time shifting the boundary work to enable purification processes in other parts of the system. The SAJ application acted as a boundary object that allowed new employees (the "technicians") to become familiar with judicial processes, but it also became the basis of a new boundary between the identities of new and old employees. On the other hand, the proposed perspective also highlights how boundary spanning can build on and benefit from the opposing boundary work that reinforces existing boundaries. In the MEDA case, the SAJ application enhanced the internal boundaries between different sections of the courts and, through that, enabled spanning the external boundaries between the courts and the citizens.

In practice, many organizations resort to "modularity" as an architectural choice in order to enhance their ability and agility in undergoing such ICT-enabled 
changes in boundary configurations. A modular approach to organizational design involves multiple modules characterized by "independence across and interdependence within their defined boundaries" (Cabigiosu \& Camuffo, 2012). This approach is widely seen as challenging and opening up traditional organizational structures, but it often clashes with other approaches that require high levels of reliability, and consequently tight integration for the purposes of control and traceability across processes (D'Adderio \& Pollock, 2014). Thus, organizations often find themselves needing to engage in a dynamic between closedness and openness where the relative stabilization of the boundaries within the system architecture, usually through interfacing standards, enables the mixing and matching of modular components (Tiwana \& Konsynski, 2010). The proposed perspective offers a view of this approach to open organizing as a process of enactment, where human and nonhuman actors shift constantly from being intermediaries to being mediators generating multiple black boxes (modules) with loosely defined boundaries as a result. Accordingly, the role of ICTs in supporting varying degrees of open organizing rests upon sophisticated architectural designs that successfully optimize the relationship between the work of intermediaries (e.g., processes contained within a module) and the work of mediators (e.g., adaptation of boundary resources such as APIs, SDKs, and regulations [Ghazawneh \& Henfridsson, 2013]).

Third, the proposed perspective highlights that the process of ICT-enabled openness often starts before ICTs are introduced, which implies that their design and implementation need to take into consideration the work that is already being done to increase the permeability of boundaries. This requires scanning the environment of ICT implementation for ongoing translation activities in order to design and introduce ICTs in ways that harness and augment these activities. In the MEDA case, this involved the SAJ application that was built on ongoing discourses calling for increased openness of the judicial system to citizens. The intertwining of ICTs with this ongoing boundary work enhanced the openness of the boundary and generated new translations across other boundaries such as the one between citizens and their lawyers. Instead of augmenting the ongoing discourses calling for increased openness of the judges' work, the introduction of the SAJ application actually compromised this existing boundary work.

Understanding these second-order consequences of boundary reconfiguration through ICT-enabled boundary work is particularly significant for attempts at using ICTs for more radical reforms to rigid systems. An example of such reforms in the public sector is the increasingly popular approach of "government as a platform" which aims to transform governments to "become an open platform that allows people inside and outside government to innovate" (O'Reilly, 2010). The design and implementation of the large-scale transformations needed for achieving the levels of openness suggested by such approaches require the mobilization of a wide range of human and nonhuman allies. Therefore, the introduction of ICTs for purposes of increased openness needs to include in its networks of implementation and use, people and artifacts that are already challenging the rigid boundaries of the system.

\section{Conclusions and Limitations}

Enabling open forms of organizing through ICTs is an increasingly important objective for a wide range of organizations in both the public and private sectors, and in both developed and developing countries. It is, however, an objective that remains challenging for organizations with rigid and bureaucratic structures. In this paper, we deployed an actor-network perspective to contribute to and enhance existing practice-based understandings of ICT-enabled open organizing by showing that "designing for openness" is, in part, a matter of problematizing, and then shifting and/or augmenting existing boundary work to generate new boundary configurations. Our case example has demonstrated that the way in which these activities are performed may have equivocal implications for organizational boundaries, and thus for the (non)achievement of openness. We hope that future research can build on these insights to investigate new dimensions and manifestations of ICT-enabled open organizing and its intertwinement with entrenched boundary configurations.

We acknowledge several limitations with the case example, as well as the theoretical and practical implications presented here. First, despite the longitudinal time frame of the case, significant changes to the SAJ application and its impact on the whole judicial system were still unfolding, which means that new boundary configurations may have emerged after the fieldwork ended. These changes could have provided other insights to the analysis - particularly in illuminating possible unintended consequences. For example, over time, as the older clerks begin to see new incentives in using the application and new clerks become more established as regular clerks instead of "technicians", the identity boundary between old and new employees may begin to blur. However, during the period of the fieldwork, this boundary was entrenched in the system and constituted an important source of challenge to the transformational potential of theapplication.

Additionally, our analysis and theorizing were aimed at a relatively high level of abstraction in which ICTs were treated as a broad category reflecting common manifestations and affordances of information and communication technologies. While the case findings 
are based on a case processing application, the theorizing is not focused on this type of ICT. Future studies could develop this theorizing in relation to specific types of ICTs that are introduced for the sake of opening rigid structures - such as social media, cloud services, or open data repositories. Finally, the problematizing, shifting, and augmenting roles of boundary work developed here do not constitute a normative typology of all possible effects that ICT can have on existing boundary work. Instead, they represent a grounded framework that presents key ideal types of ICT entanglement with existing boundary work as they emerged from our analysis. Further research is needed to further refine or expand the three types. 


\section{References}

Ahmed, A. (2007). Open access towards bridging the digital divide: Policies and strategies for developing countries. Information Technology for Development, 13(4), 337-361.

Aksulu, A., \& Wade, M. (2010). A comprehensive review and synthesis of open source research. Journal of the Association for Information Systems, 11(11), 576.

Aldrich, H. (1971). Organizational boundaries and inter-organizational conflict. Human Relations, 24(4), 279-293.

Backhouse, J., Hsu, C. W., \& Silva, L. (2006). Circuits of power in creating de jure standards: Shaping an international information systems security standard. MIS Quarterly, 30(SI), 413-438.

Baldwin, C., \& von Hippel, E. (2011). Modeling a paradigm shift: From producer innovation to user and open collaborative innovation. Organization Science, 22(6), 1399-1417.

Barrett, M., Oborn, E., Orlikowski, W. J., \& Yates, J. (2012). Reconfiguring boundary relations: Robotic innovations in pharmacy work. Organization Science, 23(5), 1448-1466.

Barrett, M., Davidson, E., Prabhu, J., \& Vargo, S. L. (2015). Service innovation in the digital age: Key contributions and future directions. MIS Quarterly, 39(1), 135-154.

Bloomfield, B. P., \& Vurdubakis, T. (1999). The outer limits: Monsters, actor networks and the writing of displacement. Organization, 6(4), 625-647.

Boudreau, K. (2007). Does Opening a Platform Stimulate Innovation? The Effect on Systemic and Modular Innovations (MIS Sloan Research Paper no. 4611-06). Retrieved from http://papers.ssrn.com/abstract $=913402$

Cabigiosu, A., \& Camuffo, A. (2012). Beyond the "mirroring" hypothesis: Product modularity and interorganizational relations in the air conditioning industry. Organization Science, 23(3), 686-703.

Callahan, K. (2007). Citizen participation: Models and methods. International Journal of Public Administration, 30(11), 1179-1196.

Callon, M. (1986). Some elements of a sociology of translation domestication of the scallops and fishermen of St Brieuc Bay. In J. Law (Ed.), Power, Action and belief: A new sociology of knowledge (pp. 196-223). London: Routledge.

Callon, M. (1999). Actor-network theory: The market test. In J. Law \& J. Hassard (Eds.), Actor network theory and after (pp. 181-195). Oxford, UK: Blackwell.

Carlile, P. R. (2002). A pragmatic view of knowledge and boundaries: Boundary objects in new product development. Organization Science, 13(4), 442-455.

Cecez-Kecmanovic, D., Kautz, K., \& Abrahall, R. (2014). Reframing success and failure of information systems: A performative perspective. MIS Quarterly, 38(2), 561-588.

Dahlander, L., \& Gann, D. M. (2010). How open is innovation? Research Policy, 39(6), 699-709.

Dewan, S., \& Ren, F. (2011). Information technology and firm boundaries: Impact on firm risk and return performance. Information Systems Research, 22(2), 369-388.

Ernst, C., \& Chrobot-Mason, D. (2011). Flat world, hard boundaries: How to lead across them. MIT Sloan Management Review, 52(3), 81.

Eservel, U. Y. (2014). IT-Enabled Knowledge Creation for Open Innovation. Journal of the Association for Information Systems, 15(11), 805-834.

Faik, I., \& Walsham, G. (2013). Modernisation through ICTs: Towards a network ontology of technological change. Information Systems Journal, 23(4), 351-370.

Faraj, S., \& Yan, A. (2009). Boundary work in knowledge teams. Journal of Applied Psychology, 94(3), 604-617.

Fishenden, J., \& Thompson, M. (2013). Digital government, open architecture, and innovation: Why public sector IT will never be the same again. Journal of public administration research and theory, 23(4), 977-1004.

Gersick, C. J. (1991). Revolutionary change theories: A multilevel exploration of the punctuated equilibrium paradigm. Academy of Management Review, 16(1), 10-36.

Ghazawneh, A. and O. Henfridsson (2013). Balancing platform control and external contribution in third-party development: The boundary resources model. Information Systems Journal 23(2): 173-192.

Gigler, B.-S., Tanner, R. B., \& Kiess, J. (2011). Enhanced social accountability through open access to data. Development Outreach, 13(2), 48-51.

Greene, N. L. (2012). Many roads to justice: Prospects for strengthening access to justice in the middle east-north Africa (mena) region: Rule of law in Morocco: A journey towards a better judiciary 
through the implementation of the 2011 constitutional reforms. ILSA Journal of International \& Comparative Law, 18, 455615.

Hannan, M. T., \& Freeman, J. (1984). Structural inertia and organizational change. American Sociological Review, 49, 149-164.

Hannan, M. T., Laszlo, P., \& Carroll, G. R. (2002). Structural inertia and organizational change revisited III: The evolution of organizational inertia (Research Papers Series, Graduate School of Business, Stanford University, Research Paper 1734).

Harman, G. (2009). Prince of networks: Bruno Latour and metaphysics. Melbourne, Australia: Re. Press.

Henfridsson, O., \& Bygstad, B. (2013). The generative mechanisms of digital infrastructure evolution. MIS Quarterly, 37(3), 907-931.

Heracleous, L., \& Barrett, M. (2001). Organizational change as discourse: Communicative actions and deep structures in the context of information technology implementation. Academy of Management Journal, 44(4), 755778.

Hitt, L. M. (1999). Information technology and firm boundaries: Evidence from panel data. Information Systems Research, 10(2), 134-149.

Jonsson, K., Holmström, J., \& Lyytinen, K. (2009). Turn to the material: Remote diagnostics systems and new forms of boundary-spanning. Information and Organization, 19(4), 233-252.

Kelly, D., \& Amburgey, T. L. (1991). Organizational inertia and momentum: A dynamic model of strategic change. Academy of Management Journal, 34(3), 591-612.

Lakhani, K. R., Lifshitz-Assaf, H., \& Tushman, M. (2013). Open innovation and organizational boundaries: Task decomposition, knowledge distribution and the locus of innovation. In A. Grandori (Ed.), Handbook of economic organization: Integrating economic and organizational theory (pp. 355-382). Cheltenham, UK: Elgar.

Lamb, R., \& Davidson, E. (2005). information and communication technology challenges to scientific professional identity. The Information Society, 21(1), 1-24.

Lamont, M., \& Molnár, V. (2002). The study of boundaries in the social sciences. Annual Review of Sociology, 28, 167-195.
Latour, B. (1987). Science in Action: How to follow scientists and engineers through society. Cambridge, MA: Harvard University Press.

Latour, B. (1988). The Pasteurization of France. Cambridge, MA: Harvard University Press.

Latour, B. (1993). We have never been modern. Cambridge, MA: Harvard University Press.

Latour, B. (1999). Pandora's hope: Essays on the reality of science studies. Cambridge, MA: Harvard University Press.

Latour, B. (2005). Reassembling the social: An introduction to actor-network-theory. Oxford, UK: Oxford University Press.

Latour, B., \& Woolgar, S. (1979). Laboratory life: The social construction of scientific facts. Beverly Hills, CA: SAGE.

Laursen, K., \& Salter, A. (2006). Open for innovation: The role of openness in explaining innovation performance among UK manufacturing firms. Strategic Management Journal, 27(2), 131150.

Law, J. (1999). After ANT: Complexity, naming and topology. In J. Law \& J. Hassard (Eds.), Actor network theory and after (pp. 1-14). Oxford, UK: Blackwell.

Law, J. (2009). Actor network theory and material semiotics. In B. S. Turner (Ed.), The new Blackwell companion to social theory (pp. 141158). Oxford, UK: Blackwell.

Levina, N., \& Vaast, E. (2005). The emergence of boundary spanning competence in practice: Implications for implementation and use of information systems. MIS Quarterly, 29(2), 335-363.

Malone, T. W., Yates, J., \& Benjamin, R. I. (1987). Electronic markets and electronic hierarchies. Communications of the ACM, 30(6), 484-497.

Monteiro, E., Pollock, N., \& Williams, R. (2014). Innovation in information infrastructures: Introduction to the special issue. Journal of the Association for Information Systems, 15(4), i-x.

O’Reilly, T. 2010. Government as a platform. In D. Lathrop \& L. Ruma (Eds), Open government: collaboration, transparency and participation in practice. Sebastopol, CA: O’Reilly Media

Oborn, E., Barrett, M., \& Davidson, E. (2011). Unity in diversity: Electronic patient record use in multidisciplinary practice. Information Systems Research, 22(3), 547-564.

Rai, A., Pavlou, P. A., Im, G., \& Du, S. (2012). Interfirm IT capability profiles and 
communications for cocreating relational value: Evidence from the logistics industry. MIS Quarterly, 36(1), 233-262.

Santos, F. M., \& Eisenhardt, K. M. (2005). Organizational boundaries and theories of organization. Organization Science, 16(5), 491508.

Sarker, S., Sarker, S., Sahaym, A., \& Bjørn-Andersen, N. (2012). Exploring value cocreation in relationships between an ERP vendor and its partners: A revelatory case study. MIS Quarterly, 36(1), 317-338.

Schlagwein, D., Conboy, K., Feller, J., Leimeister, J. M., \& Morgan, L. (2017). "Openness" with and without Information Technology: A framework and a brief history. Journal of Information Technology, 32, 297-305.

Shah, S. K. (2006). Motivation, governance, and the viability of hybrid forms in open source software development. Management Science, 52(7), 1000-1014.

Silva, L., \& Hirschheim, R. (2007). Fighting against windmills: Strategic information systems and organizational deep structures. MIS Quarterly, 31(2), 327-354.

Star, S. L. (2010). This is not a boundary object: Reflections on the origin of a concept. Science, Technology \& Human Values, 35(5), 601-617.

Streeter, L. A., Kraut, R. E., Lucas, Jr., H. C., \& Caby, L. (1996). How open data networks influence business performance and market structure. Communications of the ACM, 39(7), 62-73.

Tiwana, A., B. Konsynski, \& A. A. Bush (2010). Research commentary-Platform evolution: Coevolution of platform architecture, governance, and environmental dynamics. Information Systems Research, 21(4): 675-687.

Tkacz, N. (2012). From open source to open government: A critique of open politics.
Ephemera: Theory and Politics in Organization, 12(4), 386-405.

von Hippel, E., \& von Krogh, G. (2003). Open source software and the "private-collective" innovation model: Issues for organization science. Organization Science, 14(2), 209-223.

Walsham, G. (1995). Interpretive case studies in IS research: Nature and method. European Journal of Information Systems, 4, 74-74.

Walsham, G. (2006). Doing interpretive research. European Journal of Information Systems, 15(3), 320-330.

Warschauer, M. (2004). Technology and social inclusion: Rethinking the digital divide. Cambridge, MA: MIT press.

Whelan, E., Conboy, K., Crowston, K., Morgan, L., \& Rossi, M. (2014). The role of information systems in enabling open innovation. Journal of the Association for Information Systems, 15(11), $\mathrm{xx}$.

Whittington, R., Cailluet, L., \& Yakis-Douglas, B. (2011). Opening strategy: Evolution of precarious profession. British Journal of Management, 22(3), 531-544.

Williamson, O. E. (1981). The economics of organization: the transaction cost approach. American Journal of Sociology, 88(2), 548-577.

Yoo, Y., Henfridsson, O., \& Lyytinen, K. 2010. Research commentary-The new organizing logic of digital innovation: An agenda for information systems research, Information Systems Research, 21(4), 724-735.

Zietsma, C., \& Lawrence, T. B. (2010). Institutional work in the transformation of an organizational field: the interplay of boundary work and practice work. Administrative Science Quarterly, 55(2), 189-221. 


\section{About the Authors}

Isam Faik is an assistant professor in information systems and analytics at the National University of Singapore. His research investigates the rise of platform-based ecosystems and the resulting digital transformation of institutional fields. His recent projects are focused on the transformative effects of platform ecosystems on the nature of work and collective action, including changes in trust, formalization, routinization, mindfulness, and openness. Isam holds a PhD in management studies from the Judge Business School, University of Cambridge.

Mark Thompson is professor of digital economy at University of Exeter Business School, and strategy director of London-Based Methods, specialists in public service modernization. Mark is acknowledged as one of the architects of digital service redesign within the UK public sector. He blends the roles of academic, practitioner, and policy commentator. He has published in and reviews for a wide range of public service and information systems journals, including Academy of Management Review, Organization Science, Information and Organization, Human Relations, Journal of Public Administration, Research, and Theory, Government Information Quarterly, and Journal of Management Studies.

Geoff Walsham is an emeritus professor of management studies (information systems) at Judge Business School, University of Cambridge. In addition to the University of Cambridge, he has held academic posts at the University of Lancaster in the UK, the University of Nairobi in Kenya, and Mindanao State University in the Philippines. His research is focused on the question: Are we making a better world with information and communication technologies? He was one the early pioneers of interpretive approaches to research on information systems. Details of his publications and citations can be found at: http://scholar.google.co.uk/citations?user=xIidqewAAAAJ\&hl=en

Copyright (C) 2019 by the Association for Information Systems. Permission to make digital or hard copies of all or part of this work for personal or classroom use is granted without fee provided that copies are not made or distributed for profit or commercial advantage and that copies bear this notice and full citation on the first page. Copyright for components of this work owned by others than the Association for Information Systems must be honored. Abstracting with credit is permitted. To copy otherwise, to republish, to post on servers, or to redistribute to lists requires prior specific permission and/or fee. Request permission to publish from: AIS Administrative Office, P.O. Box 2712 Atlanta, GA, 30301-2712 Attn: Reprints or via email from publications@aisnet.org. 